\title{
THE IMPORTANCE OF DISTANCE LEARNING AND THE USE OF MOODLE EDUCATIONAL PLATFORM IN EDUCATION
}

\author{
Jelena Matijašević-Obradović ${ }^{1}$, \\ Joko Dragojlović, \\ Stefan Babović ${ }^{1}$
}

${ }^{1}$ Faculty of Law for Commerce and Judiciary in Novi Sad, University Business Academy, Novi Sad, Serbia

\begin{abstract}
:
Distance Learning is a system and the process of connecting users to distributed educational resources. This is a modern approach to education, in which the information technology emerges as an intermediary in contacts between trainers and users who are not in the same place at the same time. The concept of DLS is actually applicable to all levels of education. It can be said that a large number of world-renowned institutions of higher education has DLS form of education in their curricula. Moodle learning platform is a free, open-source platform for distance learning. Moodle system is used as the primary way for courses, as well as an additional tool to support traditional learning. The methodological approach to work includes a general analytical method, the basic quantitative data analysis and deductive approach when drawing conclusions. The research part of this paper deals with the main question - what is the real use of the Moodle platform at the Law Faculty of Economics and Justice within the study program Studies remotely - General Law? Data on the effectiveness of the application of Moodle platform at the university presented in this paper by tables and graphs and related to the number and type of users who visited the Moodle platform in the period from 8 January to 5 March indicate that the Distance learning system is a concept well accepted and successfully implemented. The data also indicate that the response of users, especially students, is beyond all expectations with the continuous progressive growth.
\end{abstract}

\section{Keywords:}

Distance Learning, Moodle platform, Faculty of Law for Commerce and Judiciary, modern education.

\section{INTRODUCTION}

Education aided by information technologies implies at least three basic components: Computer Assisted Learning - CAL; Computer Assisted Research and Distance Learning System - DLS.

CAL is most commonly used and it is very suitable for the realization of interaction between students and computers to improve the existing technology learning, making teaching more obvious, more dynamic and more interesting with the involvement of more students' senses in acquiring new knowledge. Computer-aided learning involves multimedia educational software, computer simulation, virtual reality, artificial intelligence, etc. $[1$, p. 1$]$.

\section{Correspondence:}

Jelena Matijašević-Obradović

e-mail:

jela_sup@yahoo.com 
CAR is used in higher education institutions for theoretical research in various fields of literature and empirical research using appropriate statistical software (STAT VIEW, SPSS, etc.). Theoretical research literature is almost unthinkable without the use of computer technology, because today, almost all major books, articles, studies and collections of professional and scientific meetings are translated into electronic editions and placed on publishing houses web portals, universities, libraries, schools, etc. [1, p. 1-2].

Distance learning exists for more than 100 years, but with the emergence of the Internet it gains a new dimension, and because of that it is considered a new phenomenon. The concept of DLS is actually applicable to all levels of education, from primary through secondary and higher, to various forms of education and training during working life at the workplace and outside it (lifelong learning) [7, p. 139]. Many universities in the world, in order to equalize the level of knowledge that is given to students, instead of the praxis of professors traveling to other faculties, they introduced a practice of exchanging ideas by using telecommunication technologies. The professors give lectures at the university, and it is transmitted over the Internet to other locations. With this, long-term intentions of managers in education, that instead of people, ideas are the ones that should travel, are realized which significantly reduces faculty material costs. Distance learning represents an instructional mode that does not require the presence of students and lecturers in the same room [4, p. 147].

Moodle is an open source learning platform created by pedagogical principles; it is represented in the application of the DLS concept. It is software that allows you to easily create, modify and manage online courses, as well as to easily access the content and other characteristics important for the educational institutions and their users.

Studies have shown that Moodle is the most popular e-learning system is use, both in the Republic of Serbia and in the region. An increasing number of institutions in Serbia that use this platform in the development and improvement of the teaching process also proves global popularity of Moodle system [9, p. 80-81].

This paper intends to summarize the main questions of importance in relation to distance learning system as a modern approach to education, the features of Moodle learning platform and its representation and application in the world and Serbia. After the theoretical part, with the use of relevant methodology, a brief survey regarding the representation and implementation of Moodle software in the field of higher education at the Law Faculty of Economy and Justice, will be presented.

\section{THEORETHICAL DETERMINATION}

Definitions of distance education are not unique and have changed over time, often depending on the development of technologies that have been implemented, but also the science of teaching at a distance (distance teaching), and its final result, distance learning (distance learning), especially in higher education, where distance education had appeared [7, p. 139].

Distance learning is a system and the process of connecting users to distributed educational resources. This is a completely new form of education, in which the information technology emerges as an intermediary in contacts between trainers and users who are not in the same place at the same time. Based on the application of computer networks and other modern electronic devices, this concept enables users of education services to monitor the lectures, access the educational facilities and programs, communicate with the teacher and gain a diploma (certificate) [8, p. 2].

Distance learning by Tepšić, Blueberry, Bakić $[5, \mathrm{p}$. $2]$ "means that the main carrier of communication between teachers and students is separation (at a different time and a different place - the separation of instructors - the tutor of the student). It must include two-way communication between teachers and students that aims to facilitate and support the process of education. It is used as an intermediary for the necessary two-way communication technology. "

Distance learning, above all, is a democratic form of education, because it creates all the preconditions of equality of access to information and knowledge, while significantly reducing the cost and risk of a "force" inappropriate involvement of the teaching staff, because number of qualified teachers is still proportionately small compared to the number of potential students. Because of that, there is a considerable attention paid to the development of distance education in the world [5, p. 2]. However, in addition to the advantages of the concept of distance learning, which are of great importance for modern society, Janeska and Taleska [6, p. 2] point out that "despite all the advantages, e-learning has some disadvantages. First, students must have a certain level of computer literacy. Students can also feel the lack of face to face interaction with the teacher. Assessment of student work can be problematic, because teachers don't know who has really solved the tasks, or answered the questions. In any case, e-learning cannot replace the traditional classroom environment, but it primarily enriches the content and use of new technology. " 
According to the forms of communication, there are two forms of distance learning:

Synchronous forms of distance education are based on the assumption that all users and trainers are "online" at the same time. Types of online teaching are: interactive television, computer conferencing, multi-user domains (Multi-User Domains - MUD). The main advantage of synchronous technology is the establishment of direct communication between trainers and users.

Asynchronous form of education is represented to a greater extent because it gives the user the ability to choose when and how much time to spend in the virtual classroom (distance education, audio and video cassettes, DVD, electronic mail, television educational program, and www oriented courses). Asynchronous schools are suitable for higher forms of education (complete secondary and high school) [5, p. 3].

When we talk about the representation of DLS concept, we can say that a large number of world-renowned institutions of higher education in their curricula has this form of education.

According to the data from the American Association for Distance Learning (The United States Distance Learning Association, USDLA) for 2003, there were about $3,000,000$ students on some form of distance learning. Some of the most important institutions that use DLS concept in their work in the United States are: National Technological University, Western Governors University, University of Phoenix, California Distant Learning Program, Columbia Network for Engineering Education; important institutions in Europe are: The International Council for Open and Distance Education - Oslo, United Kingdom Open University, the Virtual University Enterprises, University for Industry, etc. [7, p. 138].

In Europe, significant initiatives to develop distance learning are realized through the "European Distance Education Network" (EDEN) and the "European Association of Distance Teaching Universities Education". EDEN members from Serbia are: E-learning Network, Link group (who is the founder of the Belgrade Academy of Computer Science) and the Faculty of Economics from Subotica [7, p. 139].

Computer technology is continuously innovated and DLS concept includes significant investments by institutions that enforce them. Whether to use their own or rented kind of platform depends on the software educational institutions are going to use. The system, which is gradually gaining popularity in the world, is known as Moodle.
Moodle is a system for creating courses i.e. software package that is designed to help teachers to create quality " online " courses and to oversee the results of their students. Such e-learning systems are sometimes called "systems of distance learning," "Terms of virtual learning" and "System Manager meaningful learning". Moodle is used by universities, schools and individual instructors, first of all, in order to improve teaching by using web technology [9, p. 76]. System features faculties decide to use for managing the learning process are: high availability - the ability to handle thousands of users simultaneously; stability - the ability to withstand an increase in the number of users with no drop in performance; easy usability - the ability of the user (student or teacher) to very quickly learn how to use the system; interoperability - the ability to integrate with existing software within the institution; stability - a stable version of the software. Moodle provides continuous services to the students and teachers; security - characteristics of the system that does not represent a security risk higher than other components of the information system of the institution [3, p. 781].

As already mentioned, Moodle is a free, open-source platform for distance learning.

Moodle Learning Management page provides teachers with full support for the organization and implementation of online courses. Some of the most important Moodle options are: production of a large number of courses on a single system in various forms, planning courses - schedule of activities, calendar, the management of user roles and user groups in courses, working with existing files and educational materials, production of various types of online tests, tracking the activities of all the users, many tools for communication and collaboration, creating a dictionary of technical terms, the management system backup, statistics, access, extensive help system [2, p. 32].

Moodle was designed to be used primarily as a tool for asynchronous learning, where learning takes place at different times. However, it also contains modules for synchronous form of learning. Moodle is used as the primary means for courses, as well as an additional tool to support traditional learning. Simply put, Moodle is a tool for teachers who need to use it to improve learning [3, p. 781].

A pioneer in the application of distance learning is Medical University of Serbia in Belgrade, which in $1999 / 2000$, has started the realization of the first on-line courses. Microsoft and the Faculty of Electronics in Nis are now participating in development and implementation of e-education in Serbia [9, p. 79]. The Academic 
Network of Serbia - AMRES is vitally important for the development of distance learning in Serbia. AMRES is primarily scientific research and educational computer network, which provide modern information and communication services and the Internet connection for its members. In 2007, AMRES launched a project about the introduction of e-education in many colleges. It was decided to use already ready, open - source platform for distance learning called Moodle. A large number of educational institutions embarked on this project with the aim of increasing the quality of both the teaching and successful learning. In order to develop e-learning, the following faculties have joined the project: Faculty of Architecture in Belgrade, Faculty of Electrical Engineering in Belgrade, Faculty of Medicine in Belgrade, Faculty of Transport in Belgrade, Faculty of Forestry in Belgrade, Faculty of Philosophy in Belgrade, Faculty of Mechanical Engineering, Faculty of Science in Novi Sad, Faculty of Medicine in Novi Sad, FON in Belgrade, Faculty of Economics in Subotica, Faculty of Philology in Belgrade and Faculty of Mechanical Engineering in Belgrade [9, p. 80].

\section{METHODOLOGY, HYPOTHESIS AND DATA SOURCES USED}

Bearing in mind that the first part of this paper is dedicated to the theoretical definitions of the concept and DLS Moodle software platform, as well as their representation in the world, Europe and Serbia, this paper has primarily applied a methodological approach that involves the general analytical methods in theoretical content analysis, fundamental analysis of the data, the analysis of Moodle software application at the Law Faculty of Economics and Justice, within the study program - Study remotely-General law, and deductive approach when drawing conclusions.

If you take a baseline rule that Moodle educational platform can be accessed by different users who can be divided into two groups: administrators and ordinary users, and that there are three kinds of ordinary users (teachers - who regulate the content, students - who can view the content they are registered to, and guests - users who are not logged on to the system with a username and password, and who can view information about the courses and possibly some courses), the question that arises is - what is the real implementation of Moodle platform at the Law Faculty for the economy and the judiciary in Novi Sad, University business Academy in Novi Sad, within the study program Studies remotely - General law taking into account the number of visits and authorized regular users, divided into three groups mentioned, and the total number of accredited students per year? For the reference period we have taken the two-month period - from 08 January 2017 till 05 March 2017, classified by weeks.

\section{ANALYSIS OF MOODLE PLATFORM APPLICATION AT LAW FACULTY OF ECONOMY AND JUSTICE}

The subject of quantitative data analysis is the success in the implementation of the Moodle platform at the Law Faculty of Economics and Justice, within the study program Studies remotely - General Law. The analysis is based on the number of visits by ordinary users (students, guests, teachers) and authorized users on the front page E-Real Home, classified by weeks in the period from 8 January to 5 March, in 2017, whereby it must be kept in mind that this is undergraduate study program and that the number of accredited students for this study program is 50 , for each year.

\begin{tabular}{|c|c|c|c|c|c|}
\hline \multicolumn{6}{|c|}{ Korisnici } \\
\hline $\begin{array}{l}\text { End of } \\
\text { period } \\
\text { (weeks) } \\
\text { in } 2017 .\end{array}$ & $\begin{array}{l}\text { Authorized } \\
\text { users on the } \\
\text { front page }\end{array}$ & Guest & Student & $\begin{array}{l}\text { Lec- } \\
\text { turer }\end{array}$ & Sum \\
\hline $\begin{array}{c}\text { March } \\
05\end{array}$ & 82 & 121 & 301 & 44 & 548 \\
\hline $\begin{array}{c}\text { February } \\
26\end{array}$ & 58 & 87 & 108 & 17 & 270 \\
\hline $\begin{array}{c}\text { February } \\
19\end{array}$ & 80 & 147 & 377 & 8 & 612 \\
\hline $\begin{array}{c}\text { February } \\
12\end{array}$ & 95 & 126 & 468 & 5 & 694 \\
\hline $\begin{array}{c}\text { February } \\
05\end{array}$ & 200 & 229 & 980 & 3 & 1412 \\
\hline $\begin{array}{c}\text { January } \\
29\end{array}$ & 90 & 90 & 1070 & 0 & 1250 \\
\hline $\begin{array}{c}\text { January } \\
22\end{array}$ & 47 & 87 & 378 & 0 & 512 \\
\hline $\begin{array}{c}\text { January } \\
15\end{array}$ & 108 & 108 & 851 & 8 & 1075 \\
\hline $\begin{array}{c}\text { January } \\
08\end{array}$ & 72 & 90 & 916 & 0 & 1078 \\
\hline
\end{tabular}

Table 1. Frequency of users of the moodle platform law faculty of economics and justice for the period 08.01.-05.03. 2017

${ }^{\mathrm{a}}$ Author data from institutions 


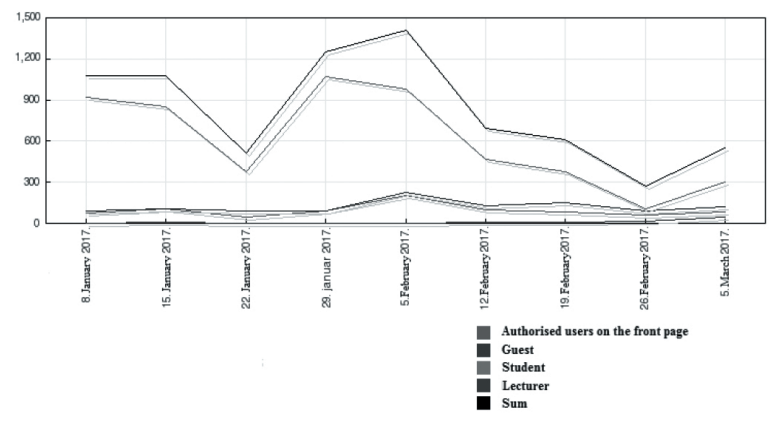

Fig. 1. The graphic data expressed in Table 1.

\section{DISCUSSION ABOUT RESULTS OF THE ANALYSIS}

As it is shown in tabular and graphical representation of users' visits to Moodle platform at the Law Faculty of Economics and Justice in the period from 8 January to 5 March, in 2017, DLS as a modern approach to education has encountered a very good response from the students. Although the mentioned period was an exam period and the number of activities on the Moodle platform was reduced, it can be concluded that the user response to Moodle platform is more than successful with the tendency of the active progression, and that the application of the DLS modern educational approaches achieve the expected results.

Performance of Moodle platform for the two-month period at the Law Faculty of Economics and Justice remains to be monitored, as well as quarterly, semi-annually and annually. The summarized results will certainly be the subject of a later analysis.

\section{CONCLUSION}

It cannot be disputed that along with the use of modern media, didactic teaching has become more dynamic and interesting, customizable to the capabilities of students. With an even better organization and improvement of the current situation, we can provide even greater support for the content, activities, better quality and durability of their knowledge.

It is obvious that the DLS concept is tremendously developing in the world. What can without any doubt be regarded as a significant advantage of distance learning is the fact that students do not lose anything in terms of teaching quality and volume of knowledge acquired through distance learning while they gain, on the other side, the opportunity to learn at a pace that suits them, at time that suits them, from wherever it suits them, making it easier to reconcile studies with other life commitments. Properly placed DLS system (technology, personnel, organization etc.), adequate teaching materials, designed and continuously upgraded in accordance with the purpose and objectives of this concept, and the proper approach to communication as an important part of distance learning can greatly contribute to achieving several key objectives of long-term development of education within the education development Strategy in Serbia until 2020. Ongoing evaluation of performance and the level of development of the concept of DLS are also very important, in accordance with the changes taking place in developed countries, and based on the experiences and attitudes of teachers and students in practice.

According to the already said, the data presented in this paper relate to proactive approach of application performance testing of Moodle platform at one faculty in the field of legal sciences and socio-humanistic education fields, based on the number and type of users' visits to Moodle platform in the period from 8 January to 5 March, in 2017. Summing up the obtained data, it was concluded that the DLS concept is well accepted and successfully implemented and that the response of users, especially students, as a separate reference category of ordinary users, is beyond all expectations (8 January 2017 - 916 visits, 29 January 2017 - 1070 visits, etc.), with continuously high growth.

\section{REFERENCES}

[1] D. Mandić, "Distance learning", 2003, p. 1, available at: http://www.edu-soft.rs/ (08.03.2017.).

[2] D. Ljubičić, "E-learning and Moodle as an educational platform", thesis, Banja Luka: University in Banja Luka, Faculty of Sciences, 2011.

[3] I. Kostić Kovačević and J. Gavrilović, "Incorporating educational software for dynamic mathematics in the system for distance learning", in: Infoteh Jahorina - Ref. E-V-7, Vol. 10, East Sarajevo: Faculty of Electrical Engineering, pp. 780-783, 2011.

[4] J. Matijašević-Obradović and I. Joksić, "The representation of the concept of Distance learning in the higher education system in Serbia", Nastava i vaspitanje, Vol. LXIII, No. 1, pp. 145-158, 2014.

[5] M. Tepšić, T. Borovnica and S. Bakić, "Systems for electronic testing of students", Primus global - ekonomija, informatika, pravo, Vol. 1, No. 1, pp. 1-10, 2015. 
[6] M. Janeska and S. Taleska, "E-learning - a new possibility of realization of the teaching process", in XVII Scientific Conference Trendovi razvoja - EUROPA 2020: A knowledge-based society, Kopaonik: Faculty of Technical Sciences University of Novi Sad, pp. 1-4, 2011.

[7] S. Pokorni, "Distance learning", Vojnotehnički glasnik, No. 2, pp. 138-146, 2009.
[8] S. Milutinović and S. Ćurčić, "Methodology of education in the art based on the application of Distance learning", in IV International Conference - Science and Informatics in Education, Vol. 2, D. Golubović, Ed. Čačak: Technical Faculty, pp. 1-7, 2012.

[9] Milićević, Z. Milićević and N. Milić, "E-learning in Serbia using Moodle software", BizInfo, Vol. 5, No. 1, pp. 71-82, 2014. 